\title{
ANALISIS KESESUAIAN LAHAN DAN DAYA DUKUNG LINGKUNGAN UNTUK BUDIDAYA RUMPUT LAUT DI PERAIRAN BAUBAU
}

\author{
Jamilah, Dosen Jurusan Pendidikan Biologi, \\ Fakultas Tarbiyah dan Keguruan, UIN Makassar, \\ 08134240876, email: jamilah_alamsyah@yahoo.com
}

\begin{abstract}
Abstrak: Pada saat ini, peningkatan budidaya Rumput laut di perairan Bau-bau mengalami peningkatan. Penelitian ini bertujuan untuk menganalisis (1). Tingkat kesesuaian lahan dan Daya Dukung Lingkungan untuk pengembangan budidaya rumpul laut di perairan kota Baubau, Sulawesi Tenggara (2). Fluktuasi kesesuaian dan daya dukung lingkungan untuk pengembangan budidaya rumput laut berdasarkan perubahan parameter lingkungan. Metode yang digunakan adalah penelitian eksploratif dengan menggunakan metode survey dan pengukuran langsung di lapangan. Data yang diperoleh dianalisis secara deskriptif yang dilaporkan dalam bentuk Tabel dan Gambar. Hasil penelitian menunjukkan bahwa setelah melalui analisis kesesuaian lahan dan daya dukung lahan, perairan Kota Bau Bau sesuai untuk budi daya rumput laut 196,63 Ha dengan kapasitas lahan tersedia adalah 152,30 Ha. Estimasi unit media budi daya untuk budi daya rumput laut sebanyak 524 unit dengan prakiraan produksi berkisar antara $943,82-1415,74$ ton/tahun.
\end{abstract}

Kata Kunci: Kesesuaian Lahan, Daya Dukung, Rumput Laut, Perairan.

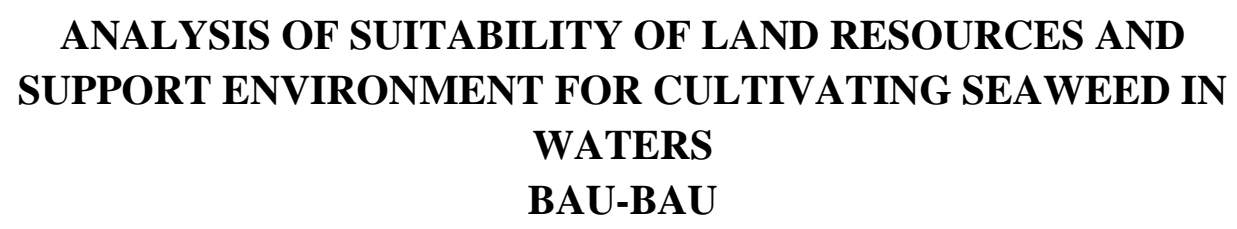

Abstract: At this time, the increase in aquaculture (maricultur) smells waters has increased.. This study aims to analyze (1). Level land suitability and Environmental Carrying Capacity for aquaculture development in the municipal waters Baubau, Southeast Sulawesi (2). Fluctuations suitability and carrying capacity of the environment for aquaculture development based on changing environmental parameters. The experiment was conducted in the Laboratory of Chemical Oceanography Laboratory Marine Science Department Faculty of Marine Sciences and Fisheries University of Hasanuddin Makassar. The method used was exploratory study using survey method and 
direct measurement in the field. Data were analyzed descriptively reported in the form of Tables and Figures. The results showed that after a through analysis of land suitability and carrying capacity of the land, the waters of Bau Bau suitable for seaweed cultivation with a capacity of 196.63 hectares of land available is $152.30 \mathrm{Ha}, 742.12 \mathrm{Ha}$. Estimated unit cultivation medium for the cultivation of seaweed as 524 units with production forecasts ranged from 943.82 to 1415.74 tons / year.

\section{Keywords: Suitability Of Land, Carrying Capacity, Seaweed, Marine}

Kota Bau bau terbentuk melalui Undang-Undang Republik Indonesia Nomor 13 Tahun 2001. Sebagai salah satu kota di wilayah Provinsi Sulawesi Tenggara, Kota Baubau mempunyai potensi dan peran strategis dalam menggerakkan pembangunan daerah di Provinsi Sulawesi Tenggara serta Indonesia Timur pada umumnya. Disamping sebagai pusat pelayanan, kota Baubau juga sebagai pusat aktivitas ekonomi dan di masa depan juga sebagai terminal bahan bakar minyak yang jangkauan pelayanannya adalah wilayah Indonesia bagian Timur. Kawasan pesisir Kota Bau bau memiliki sumber daya yang menunjang berbagai kepentingan dan aktivitas ekonomi masyarakat di Kota Baubau dan daerah di sekitarnya. Beberapa fasilitas umum dan aktivitas masyarakat yang terdapat di kawasan pesisir Kota Baubau antara lain: pelabuhan (pelabuhan umum, pelabuhan ferry, pelabuhan khusus (terminal transit) PERTAMINA, pelabuhan perikanan), Pangkalan Pendaratan Ikan, tempat beroperasinya perahu penyeberangan antar pulau, kawasan industri dan pergudangan, pasar dan sebagainya. Dengan demikian maka posisi pesisir Kota Baubau mempunyai nilai sosial ekonomi yang tinggi dan penting baik bagi masyarakat, pelaku usaha dan pemerintah.

Kota Baubau secara geografis berada pada $5^{\circ} 15^{\prime}-5^{\circ} 32^{\prime}$ Lintang Selatan dan $122^{\circ} 30^{\prime}-122^{\circ} 46^{\prime}$ Bujur Timur, membentang di tengah Kabupaten Buton. Kota Baubau terdiri dari tujuh kecamatan dengan pusat pemerintahan di Kecamatan Murhum. Terdapat 6 (enam) wilayah kecamatan pesisir yakni Kecamatan Wolio, Kecamatan Betoambari, Kecamatan Bungi, Kecamatan Lea-Lea, Kecamatan Murhum, dan Kecamatan Kokalukuna. Kota Baubau yang terletak di Pulau Buton Dengan panjang garis pantai kurang lebih 55,92 km dengan luas $221 \mathrm{~km}^{2}$, jumlah penduduk 130.862 (BPS 2010), sangat potensial untuk dikembangkan sektor kelautan khususnya budidaya laut. Tetapi pada proses pengelolaannya harus secara hati-hati dan terarah.

Kebijakan dan strategi pengembangan perikanan Budidaya Sulawesi Tenggara yang mencanangkan sebagai Provinsi rumput laut yang artinya setiap kabupaten/kota perlu menjadikan rumput laut sebagai komoditas unggulan hingga pelosok pedesaan. Sejalan dengan itu strategi dan kebijakan pengembangan sektor perikanan dan kelautan kota Bau bau yaitu: 
1. Memperluas dan menambah unit usaha budidaya yang telah ada atau Ekstensifikasi,

2. Meningkatkan jumlah dari setiap unit usaha budidaya atau Intensifikasi dan

3. Menambah jenis atau spesies budidaya yang unggul atau baru yang disebut Diversifikasi.

Ghufron (2010), pada saat ini peningkatan budidaya laut (maricultur) di perairan Baubau mengalami peningkatan, baik dari segi luas lahan maupun jenis budidaya. Usaha Budidaya ini menjadi alternatif usaha yang dapat meningkatkan kesejahteraan masyarakat. Hanya saja kegiatan budidaya di perairan Baubau belum dikelola dengan baik.

Anggoro (2004), salah satu hal yang harus diperhatikan dalam pengembangan budidaya rumput Laut adalah adanya perubahan parameter lingkungan karena hal tersebut mempengaruhi luasan dan area lokasi pengembangan Budidaya oleh karena itu sangat penting dikaji bagaimana tingkat kesesuaian budidaya laut dan daya dukung lingkungan terhadap perubahan parameter lingkungan sehingga pada prakteknya didapatkan hasil yang maksimal (Agusta, 2012). Salah satu faktor yang menyebabkan perubahan parameter lingkungan di Baubau karena dialiri oleh dua sungai yang bermuara di perairan Baubau. Pada umumnya setelah hujan lebat, aliran sungai Baubau akan berubah menjadi kecoklatan karena mengandung lumpur yang berasal dari kegiatan di daerah hulu sungai. Analisa detail spesifikasi wilayah untuk pemanfaatan areal budidaya rumput laut yang dilakukan selama ini umumnya tanpa diawali dengan penelitian tentang analisa kesesuaian lahan dan kondisi daya dukung lahan serta status lokasi sehingga sangat mempengaruhi keberhasilan dan keberlanjutan usaha budidaya (Nontji, 2005).

Tumpang tindihnya pemanfaatan dan belum tertipnya penggunaan lahan atau kawasan serta belum adanya pengelolaan budidaya yang jelas dan terkontrol sehingga berpotensi merusak lingkungan dan menjadi ancaman bagi sumberdaya tersebut (DKP, 2002). Agar budidaya rumput laut dapat berhasil maksimal, maka perlu dilakukan analisis kesesuan lahan yang mencakup kondisi lingkungan yang terdiri dari parameter fisika dan kimia serta daya dukung lainnya yang harus sesuai dengan jenis budidaya yang akan dikembangkan.

\section{METODE PENELITIAN}

Desain penelitian yang adalah penelitian eksploratif dengan menggunakan metode survey dan pengukuran langsung di lapangan. Sampel berasal dari perairan kota Bau-bau, Provinsi Sulawesi Tenggara, Penentuan titik pengambilan sampel dilakukan mengacu pada fisiografi lokasi, agar sedapat mungkin bisa mewakili atau menggambarkan keadaan perairan tersebut. Sedangkan pengujian sampel dilaksanakan di Laboratorium Kimia Oseanografi Jurusan Ilmu Kelautan Fakultas Ilmu Kelautan dan Perikanan Universitas Hasanuddin Makassar. Penelitian ini dilaksanakan pada bulan Mei sampai Juli 2012. 


\section{Pengukuran Parameter Fisika}

Suhu perairan diukur dengan menggunakan water quality checker tipe Horiba U10A di setiap titik sampling. Kecepatan Arus dilakukan dengan menggunakan layanglayang arus, stop watch serta kompas untuk melihat arah pergerakan massa air laut. Material Dasar Perairan dengan mempergunakan alat Egman grab sampler dan kemudian dianalisis di laboratorium. Penetapan tekstur tanah menggunakan metode pengendapan sederhana. Muatan Padatan Tersuspensi (MPT) menggunakan gravimetrik dan Salinitas diukur menggunakan water checker tipe Horiba U10A (Herfinalis, 2008).

\section{Pengukuran Parameter Kimia}

$\mathrm{pH}$ dan oksigen terlarut diukur dengan menggunakan water checker tipe Horiba U10A, fosfat dianalisis menggunakan spectrophotometer Visible. Pengukuran Nitrat menggunakan spektrofotometer Visible (Hutagalung dan Rozak, 1997). Data yang diperoleh dianalisis secara deskriptif yang dilaporkan dalam bentuk Tabel dan Gambar. Untuk mendapatkan kelas kesesuaian maka dibuat matrik kesesuaian perairan untuk parameter fisika dan kimia. Penyusunan matrik kesesuaian perairan merupakan dasar dari analisis keruangan melalui skoring dan faktor pembobot. Hasil skoring dan pembobotan di evaluasi sehingga didapat kelas kesesuaian yang menggambarkan tingkat kecocokan dari suatu bidang untuk penggunaan tertentu. Tingkat kesesuaian dibagi atas tiga kelas yaitu : Kelas S1 : Sangat Sesuai (Highly Suitable), Kelas S2 : Sesuai (Suitable), Kelas N : Tidak Sesuai (Not Suitable).

\section{HASIL DAN PEMBAHASAN}

Berdasarkan hasil pengukuran parameter fisika kimia perairan yang bersentuhan dengan kriteria kelayakan lahan untuk budidaya rumput laut memperlihatkan karakteristik setiap lahan memiliki kelas kesesuaian lahan yang sama dengan skoring yang beragam. Kondisi setiap parameter fisika kimia perairan di setiap kecamatan pesisir umumnya bervariasi baik yang berada dalam kisaran nilai optimum maupun lebih rendah ataupun lebih tinggi dari nilai optimum untuk budi daya rumput laut. Luas kawasan perairan yang termasuk dalam tingkat kesesuaian S2 (sesuai) di setiap kecamatan

Hasil analisis memperlihatkan perairan Kota Bau Bau berada pada kelas sesuai (S2) dan kelas tidak sesuai $(\mathrm{N})$ untuk budidaya rumput laut (seaweed). Adanya faktorfaktor pembatas yang agak serius untuk mempertahankan tingkat perlakukan yang diterapkan mempengaruhi kesesuaian lahan di perairan Bau Bau. Batasan nilai parameter yang berhubungan dengan kegiatan budidaya rumput laut (sea weed), yang perlu mendapat perhatian adalah kedalaman, kecepatan arus, nitrat, fosfat, dan salinitas.

Kecepatan arus berperan penting dalam keberhasilan suatu kegiatan budidaya baik pada sistem penjangkaran dan sirkulasi air (Akbar dan Sudaryanto, 2001), pengangkutan unsur hara (Sudjiharno et al, 2001). Pergerakan masa air dapat mencegah terkumpulnya 
kotoran pada tallus, sehingga aktivitas fotosintesa dapat berjalan dengan baik. Masukan yang diberikan adalah pembersihan organisme pengganggu atau kotoran yang menempel pada instalasi budidaya secara kontinyu.

Nitrat dan fosfat merupakan unsur yang berperan dalam menyokong pertumbuhan baik dalam pembentukan protein maupun aktivitas metabolisme. Pertumbuhan dan biomassa dapat tercapai dengan baik jika variabel ini tercukupi. Supriharyono (2004) dan Hutabarat (2000) mengatakan bahwa, fosfat merupakan unsur hara dalam perairan yang esensial untuk pertumbuhan tanaman. Fosfat dipergunakan oleh tanaman untuk membangun proteinnya (Basmi, 1999). Walaupun kedua unsur ini sangat penting bagi pertumbuhan rumput laut, tetapi pada kondisi berlebihan akan menyebabkan peledakan mikroalga lainnya.

Penilaian daya dukung terhadap lahan budidaya bertujuan untuk mempertahankan atau melestarikan potensi sumberdaya alam dari areal tersebut pada batas-batas penggunaan yang diperkenankan atau yang dimungkinkan. Dengan pendekatan ini maka akan dapat diketahui kapasitas dari suatu kawasan atau ekosistem yang dinilai, yang selanjutnya akan dapat merupakan ukuran dan/atau nilai pendugaan terhadap kualitas sumberdaya alam dan lingkungan (Augusta, 2012).

Dalam penilaian daya dukung untuk budidaya laut yang menjadi pertimbangan adalah keberlangsungan budidaya serta daya dukung lahan. Keberlangsungan budidaya terkait dengan factor eksternal lainnya yang tidak termasuk dalam parameter kesesuaian lahan, namun dominan pengaruhnya terhadap aktifitas budidaya laut. Sementara daya dukung lahan menyangkut kapasitas lahan yang tersedia sertu jumlah media budidaya yang dapat dipenuhi dalam lahan perairan yang sesuai.

Berdasarkan hasil analisis kesesuaian lahan, sebagian besar perairan Kota Baubau merupakan perairan yang sesuai untuk budidaya rumput laut. Namun dalam menentukan kawasan perairan yang tepat untuk pengembangan aktifitas budidaya rumput laut masih perlu mempertimbangkan kondisi fisik perairan lainnya yang tidak terkategorikan dalam parameter kesesuaian lahan karena menyangkut daya tahan unit budidaya. Selain itu, juga mempertimbangkan aktifitas pemanfaatan laut, seperti kegiatan pelayaran dan aktifitas kemaritiman lainnya. Pertimbangan tersebut dimaksudkan agar kegiatan budidaya berlangsung kontinyu.

Dalam pengembangan budidaya, seyogyanyalah ketahanan media budidaya menjadi perhatian terkait dengan keberlanjutan usaha di masa datang. Salah satu faktor yang mempengaruhi adalah kondisi gelombang tinggi karena menyebabkan kerusakan pada media budidaya. Pertimbangan daerah dengan kondisi gelombang besar walaupun pada lahan yang sesuai untuk budidaya rumput laut menjadi satu kategori sebagai daerah yang kurang aman karena berpotensi pada kerugian usaha terkait kerusakan media budidaya. Mengenai kondisi gelombang, hasil observasi dan wawancara menunjukkan 
bahwa pada perairan Kecamatan Murhum, dan perairan bagian utara Kecamatan Betoambari dan sebagian Kecamatan Wolio merupakan perairan dengan kondisi gelombang besar di musim barat dengan tinggi di atas 1 meter.

Berlangsungnya dua musim serta dua musim peralihan yang secara umum terjadi di Indonesia berpotensi mempengaruhi aktifitas budidaya terutama ketika musim penghujan. Curah hujan yang tinggi, pada kondisi tanah telah jenuh air akan menyebabkan terjadinya limpasan air di permukaan tanah menuju ke cekungan sungai. Masuknya air ke sungai disertai angkutan sedimen suspensi dan sedimen dasar serta kadar salinitas air tawar. Selanjutnya, aliran air di sungai menuju ke muara dan akhirnya masuk ke laut. Penyebaran air sungai di laut mempengaruhi kondisi kualitas air laut terutama perubahan kadar salinitas yakni menurunnya kadar salinitas, dan perubahan sedimen suspensi dengan meningkatnya kandungan sedimen suspensi di sekitar muara sungai. Perubahan yang terjadi berdampak pada tingkat pertumbuhan spesies yang dibudidayakan yang dapat menyebabkan kematian spesies budidaya.

\section{KESIMPULAN}

Hasil pengukuran kondisi parameter fisika dan kimia Kota Bau Bau, setelah melalui analisis kesesuaian lahan dan daya dukung lahan menunjukkan adanya potensi kesesuaian lahan budidaya rumput laut di perairan Kecamatan Kokalukuna dan Kecamatan Lea Lea. Analisis kesesuaian lahan dan daya dukung lahan, perairan Kota Bau Bau sesuai untuk budidaya rumput laut 196,63 Ha dengan kapasitas lahan tersedia adalah 152,30 Ha dengan Estimasi unit media budi dayabudi daya rumput laut sebanyak 524 unit dengan prakiraan produksi berkisar antara 943,82 - 1415,74 ton/tahun.

\section{SARAN}

Perairan Kota Baubau yang perairannya tidak di peruntukan untuk budidaya rumput laut, maka perlu di analisis lebih lanjut dalam rangka pengembangannya kedepan. Analisis dilakukan dengan melihat potensi lahan yang ada serta pemanfaatan lahan yang telah berlangsung.

\section{DAFTAR PUSTAKA}

Anggoro. S. 2004. Pengelolaan Kawasan Konservasi Laut Daerah, MSDP. UNDIP, Semarang. Semarang.

Agusta. C. Paulus. 2012. Model Pengembangan Minapolitan Berbasis Budidaya Laut di Kab. Kupang. Desertasi. IPB. Bogor

Basmi,J. 1999. Ekosistem Perairan : Habit dan Biota. Fakultas Perikanan dan lmu Kelautan. Instistut Pertanian Bogor. Bogor. 
Departemen Kelautan dan Perikanan. 2002. Modul Sosialisasi dan Orientasi Penataan Ruang, Laut, Pesisir dan Pulau-Pulau Kecil. Ditjen Pesisir dan Pulau-Pulau Kecil. Direktorat Tata Ruang Laut, Pesisir dan Pulau-Pulau Kecil. Jakarta.

Ghufron. M. H. Kordi. 2010. Marikultur Prinsip dan Praktek Budidaya Laut. Penerbit Andi. Yogyakarta.

Herfinalis. 2008. Padatan tersuspensi total di Pulau Kabaena, Muna dan Buton. Pusat Penelitian Oseanografi, Bidang dinamika laut. LIPI.

Hutagalung H. P. dan A. Rozak. 1997. Penetuan Kadar Nitrat. Metode Analisi Air Laut, Sedimen dan Biota. H. P Hutagalung, D. Setiapermana dan S.H. Riyono (Editor). Pusat Penelitian dan Pengembangan Oceanologi. LIPI. Jakarta.

Nontji, A. 2005. Laut Nusantara. Edisi revisi. Penerbit Djambatan. Jakarta.

Sudjiharno., M.Meiyana., dan S. Akbar. (2001). Pemanfaatan Teknologi Rumput Laut dalam Rangka Intensifikasi Pembudidayaan. Bulletin Budidaya Laut. DKP. Balai Budidaya Laut. Lampung.

Supriharyono. (2004). Pengelolaan ekosistem terumbu karang. Djambatan. Surakarta. 